\title{
CHEMOSPHERE
}

\section{Effect of reducing conditions on sludge melting process}

\author{
Yi-chin Huang, Kung-cheh Li * \\ Graduate Institute of Environmental Engineering, National Taiwan University, 71 Chou-Shan Rd., Taipei 10617, Taiwan, ROC
}

Received 30 November 2001; received in revised form 26 August 2002; accepted 23 September 2002

\begin{abstract}
The objective of this study was to compare the effects of $\mathrm{CO} / \mathrm{CO}_{2}$ reducing conditions with those of air oxidizing conditions on the pouring temperature of the sludge melting process and the heavy metal leachability of the resultant sludge slag. Synthetic sludge ash composed of $\mathrm{SiO}_{2}, \mathrm{CaO}$ and $\mathrm{Al}_{2} \mathrm{O}_{3}$, as well as sewage sludge ash generated from a laboratory incinerator was employed. The experimental results indicated that the pouring temperatures are significantly reduced under the reducing conditions of $\mathrm{CO} / \mathrm{CO}_{2}$, or 24 and $77^{\circ} \mathrm{C}$ lower than under air conditions for synthetic and sludge ash, respectively. The heavy metal leaching tests further indicate lower heavy metal concentrations present in the leachate under the reducing conditions, notably an order of magnitude lower in Zn. However, X-ray diffractogram indicates similar peaks for these two slags produced under different conditions.

(c) 2002 Elsevier Science Ltd. All rights reserved.
\end{abstract}

Keywords: Sludge melting process; Pouring temperature; Heavy metal leachate; X-ray diffractogram

\section{Introduction}

The disposal of a large quantity of the sewage sludge in landfill in Taiwan has become a major issue because of public resistance and the unavailability of landfill sites. The best strategy is to reduce sludge quantity during the wastewater treatment process. If not feasible, sludge reduction and recovery should be a top priority in the subsequent sludge management system. Among many alternatives for sludge quantity reduction, sludge melting process has received considerable attention since 1990s (Sakai et al., 1990; Yashiki and Murakami, 1991). A typical coke-bed melting process is shown in Fig. 1. The sludge is fed on the top of the furnace and dropped on the coke bed. In this process, the temperature is maintained at $1350-1500{ }^{\circ} \mathrm{C}$ in order to melt the inorganic components and decompose the organic contents (Oku et al., 1990; Ohshima and Masuta, 1991). The

\footnotetext{
${ }^{*}$ Corresponding author. Tel.: +886-2-23698112; fax: +886-223638173.

E-mail address: kcli@ccms.ntu.edu.tw (K.-c. Li).
}

melted material flows through the coke bed, is cooled in water or air, and ends up as the sludge slag, which can be used as construction materials, e.g., as aggregates for paving. After post-melting or sintering, the slag can also form the blocks and other crystal materials (Bijen, 1996; Endo et al., 1997; Okuno and Takahashi, 1997; Wiebusch and Seyfried, 1997).

Several concerns need to be addressed. The first is the fate of heavy metals under such high temperature conditions. A few studies indicate that more than $60 \%$ of $\mathrm{Cd}, \mathrm{Pb}, \mathrm{Zn}$ and $\mathrm{Cu}$ are present in the slag, and ver $60 \%$ of $\mathrm{Ni}, \mathrm{Cr}$ and $\mathrm{As}$ are associated with fly ash (Takaoka et al., 1997). The heavy metals leaching from the fly ash and the melted slag are related to the leaching methods, the $\mathrm{pH}$ of the extracts, and the diameter of the slag (Ozaki et al., 1997). Nishino and Tahara (1998) further indicate that the amount of metal leaching from the slag is two to three orders of magnitude less than that from the original ash. To be able for practical applications of slag under different environmental conditions, the stability of metals associated with the slag must be quantified. The second concern is to optimize the temperature used in the melting process, as the operating temperature 


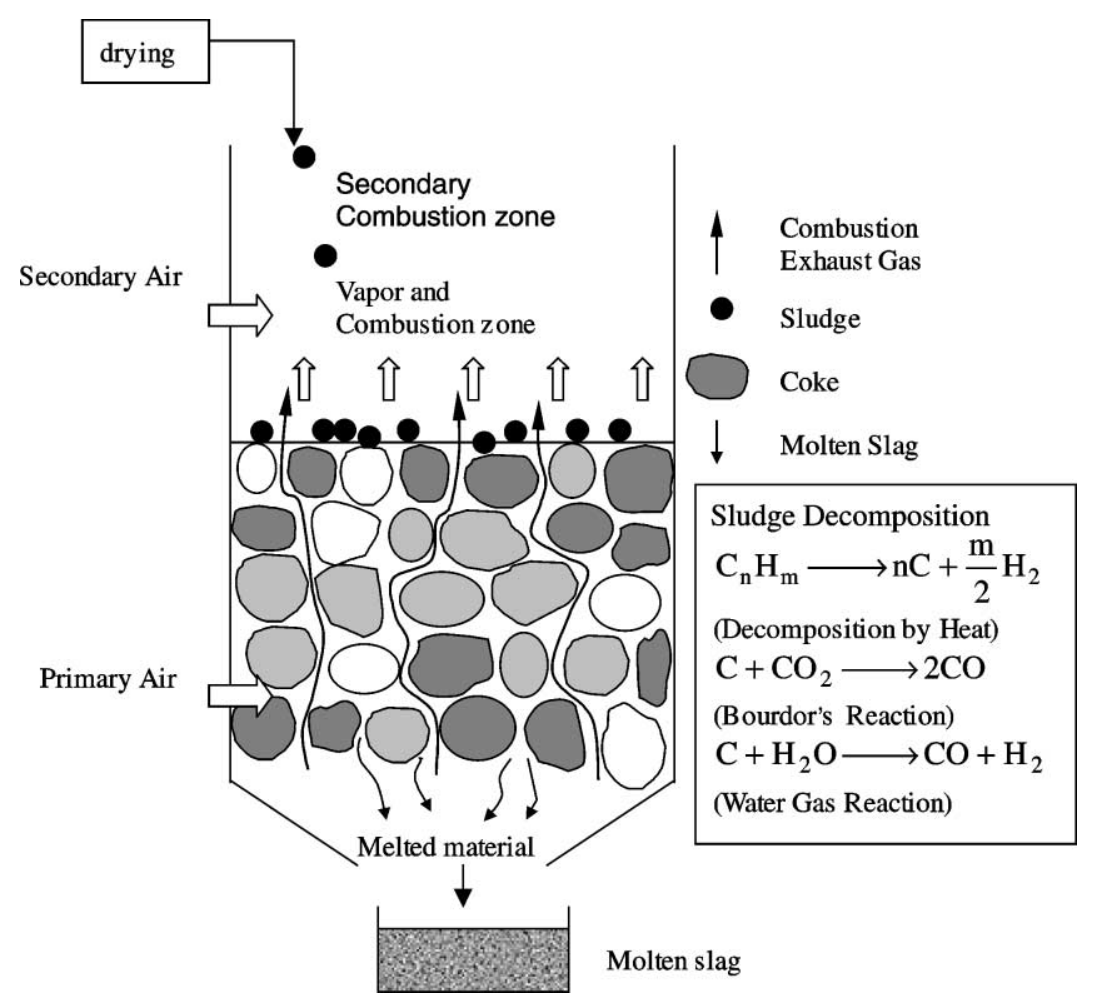

Fig. 1. Schematic diagram of coke-bed melting furnace.

clearly affects fuel consumption (Murakami et al., 1991a). To select a relatively low temperature in the melting process, it has been reported that the basicity index (weight ratio of $\mathrm{CaO} / \mathrm{SiO}_{2}$ ) could be used (Murakami et al., 1991b). The basicity associated with the relatively low temperature was reported to be 1.0 (Murakami et al., 1991b; Chen and Ouyang, 1993; Wang and Shao, 1993; Nishino and Tahara, 1998).

Typically, the pouring temperature, defined as the temperature at which the melted tested cone flows over the base and its height becomes one-third of the resulting bottom width (Murakami et al., 1991b), is determined in the laboratory under air or argon conditions. This value can serve as a referenced temperature to estimate the operating temperature in actual operation. In reality, the operating temperature also depends on the fluidity of the melted materials, and the water content of the feed sludge.

Several factors influence the pouring temperature, including for example, the distribution of $\mathrm{CaO}, \mathrm{SiO}_{2}$ and $\mathrm{Al}_{2} \mathrm{O}_{3}$. Unfortunately, the laboratory conditions for determining the pouring temperature differ greatly than those present in a coke environment. The coke bed is surrounded by a reducing state of $\mathrm{CO}$ and $\mathrm{CO}_{2}$, with a typical weight ratio of $\mathrm{CO} / \mathrm{CO}_{2}=1.5$ (Kitamura, 1999). Thus, the preset operating temperature determined from the laboratory under air conditions may be insufficient or excessive in a real plant operation. Consequently, this study was undertaken to investigate the effect of $\mathrm{CO} / \mathrm{CO}_{2}$ reducing conditions on the pouring temperature of the sludge melting process. Moreover, the heavy metal leachability of the resultant sludge slag was also studied.

\section{Materials and method}

The experiment was divided into two parts to evaluate the effects of the reducing conditions $(60 \mathrm{wt} \%$ $\mathrm{CO}+40 \mathrm{wt} \% \mathrm{CO}_{2}$ ) on the sludge melting process. The first part used synthetic sludge ash and the second used sewage sludge ash.

\subsection{Preparing the sludge samples}

The $\mathrm{SiO}_{2}, \mathrm{CaO}$ and $\mathrm{Al}_{2} \mathrm{O}_{3}$ samples were used to prescribe the synthetic sludge. The purity of the reagent in this test exceeded $97 \%(\mathrm{w} / \mathrm{w})$, and, after grinding and sieving, the diameters of the samples were smaller than $0.127 \mathrm{~mm}$. Thereafter, they were dispensed according to weight ratios, which were used as an operational parameter.

The synthetic sludge samples with 55 combinations of $\mathrm{SiO}_{2}, \mathrm{CaO}$ and $\mathrm{Al}_{2} \mathrm{O}_{3}$ corresponding to the integer 
points of three coordinates on the pouring temperatureisotherm triangle were used for measuring the pouring temperature. Each combination was tested in triplicate in both air and $\mathrm{CO} / \mathrm{CO}_{2}$ systems. After the 55 integer points were tested in the triangular pyramid test, several decimal fraction points on the pouring temperatureisotherm triangle, such as 5:2.5:2.5, were selected near the low temperature points to re-run the same experiment. The results associated with every point considered in the experiment were analyzed, and compared between two systems.

The sewage sludge, from a sewage treatment plant, Taipei, Taiwan, was burned at $900{ }^{\circ} \mathrm{C}$ in a lab-scale incinerator. After grinding and sieving to $0.127 \mathrm{~mm}$, the sludge ash was stored in an oven. The sludge ash was digested by the premixed $\mathrm{HF}, \mathrm{HNO}_{3}$, and $\mathrm{HClO}_{4}$ acids, filtered, and its metal composition was determined by inductivity coupled plasma-atomic emission spectrometer (ICP-AES), with a sensitivity of ppm.

The premixed $\mathrm{CO} / \mathrm{CO}_{2}$ gas $\left(\mathrm{CO} / \mathrm{CO}_{2}\right.$ volume ratio 2.4:1, weight ratio 60:40) used in this study was obtained from a chemical manufacturer.

\subsection{TCLP test}

The method for the toxicity characteristic leaching procedure (TCLP) follow that of Taiwan EPA's Standard Method NIEA R201.11 (ROC-EPA, 1997). The liquid-to-solid weight ratio was 20:1, with the extraction solution of acetic acid $(\mathrm{pH}=2.9)$. The inductivity coupled plasma-mass spectrometer (ICP-MS) was used for metal analysis with a sensitivity in ppb range.

Table 1

Major chemical constituents of sludge ash from sewage treatment plant

\begin{tabular}{lc}
\hline Composition & Concentration $(\%)$ \\
\hline $\mathrm{SiO}_{2}$ & 38.5 \\
$\mathrm{Al}_{2} \mathrm{O}_{3}$ & 7.8 \\
$\mathrm{MgO}$ & 0.6 \\
$\mathrm{P}_{2} \mathrm{O}_{5}$ & 14.1 \\
$\mathrm{CaO}$ & 3.6 \\
$\mathrm{Fe}_{2} \mathrm{O}_{3}$ & 7.8 \\
$\mathrm{Na}_{2} \mathrm{O}$ & 0.4 \\
$\mathrm{~K}_{2} \mathrm{O}$ & 0.1 \\
\hline
\end{tabular}

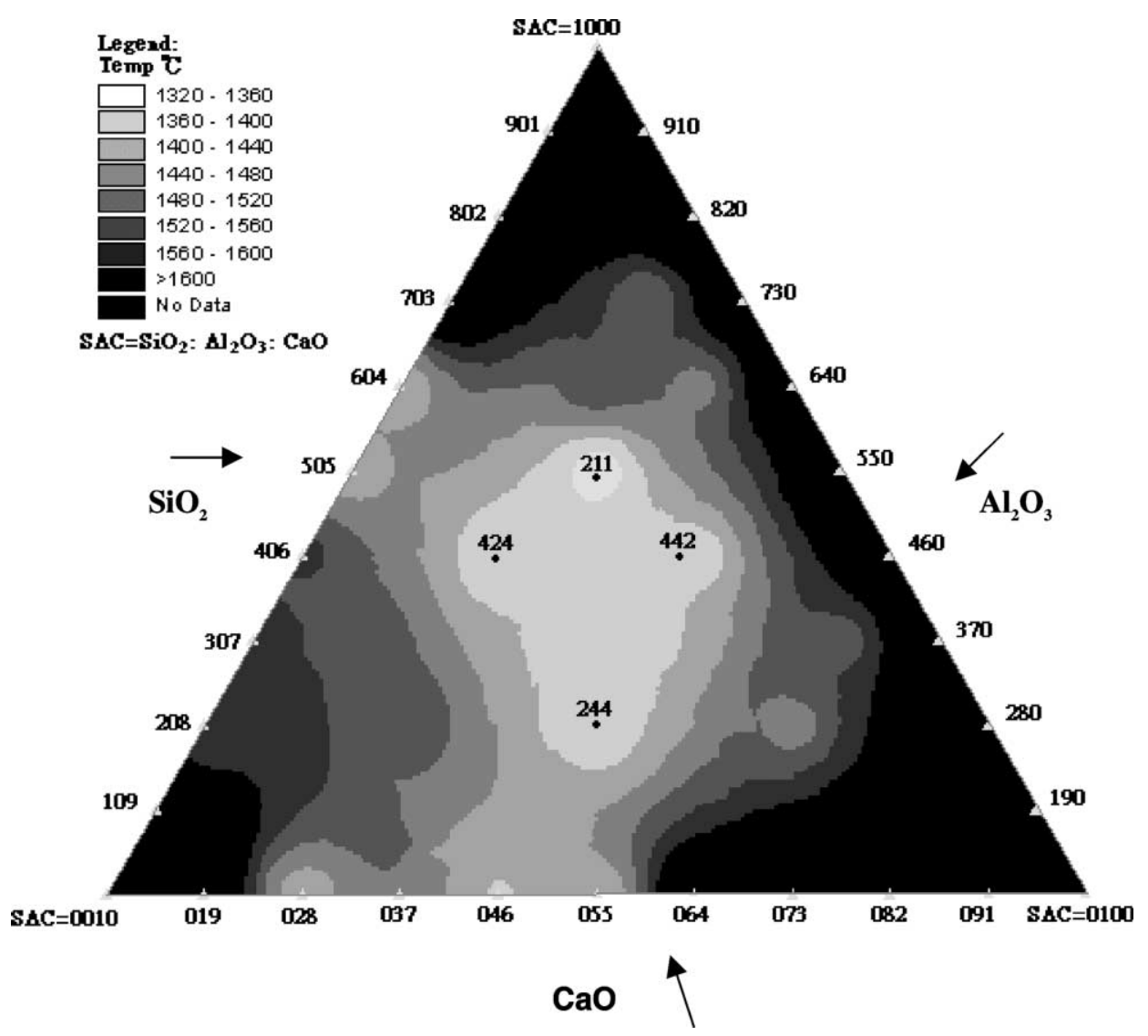

Fig. 2. Isotherms of pouring temperature under air conditions for synthetic sludge ash. 


\subsection{Triangular pyramid test}

The triangular pyramid test in a tube furnace (carbolite) was used for determining the melting and pouring temperatures of samples. Samples were molded to the triangular pyramid pattern before they were placed into the furnace. A total of four sample tiles, including eight samples, could be employed during each test run. The highest temperature was set at $1600{ }^{\circ} \mathrm{C}$, and the temperature increase was set at $5{ }^{\circ} \mathrm{C} / \mathrm{min}$, under conditions of either air or $\mathrm{CO} / \mathrm{CO}_{2}$. A high-resolution video system with an infrared camera recorded the shapes of the samples as they were heated to obtain the pouring temperatures. The increase in the temperature in the furnace was recorded. After meltdown, the molten samples were cooled in air in the furnace, and the tape was then replayed to determine the deformation temperature.

\subsection{XRD test}

The X-ray diffractogram (XRD) analysis was performed (MAC Sience MXP18) under the operating conditions of $30 \mathrm{kV}$ and $30 \mathrm{~mA}$. Samples were ground and sieved to a particle size smaller than $0.127 \mathrm{~mm}$, and $\mathrm{XRD}$ data were obtained by using $\mathrm{CuK}_{\alpha}$ radiation at a scanning rate of 4 degree/min. The peaks were identified using the joint committee on powder diffraction standards database.

\section{Results and discussion}

Table 1 indicates that the main chemical components of the sewage sludge ash are $\mathrm{SiO}_{2}(38.5 \%), \mathrm{P}_{2} \mathrm{O}_{5}(14.1 \%)$, $\mathrm{Al}_{2} \mathrm{O}_{3}(7.8 \%), \mathrm{Fe}_{2} \mathrm{O}_{3}(7.8 \%)$ and $\mathrm{CaO}(3.6 \%)$. The high $\mathrm{SiO}_{2}$ content of the samples may be due to the soil and sand entering the sewer system.

\subsection{Effect of the reducing conditions on the pouring temperature}

A preliminary study of synthetic sludge ash was first conducted to assess the feasibility of reducing the pouring temperature by shifting the experimental conditions from air to $\mathrm{CO} / \mathrm{CO}_{2}$. Fig. 2 shows isotherms plotted on a ternary phase diagram of melting synthetic ash under air conditions. The SAC acronym is an ab-

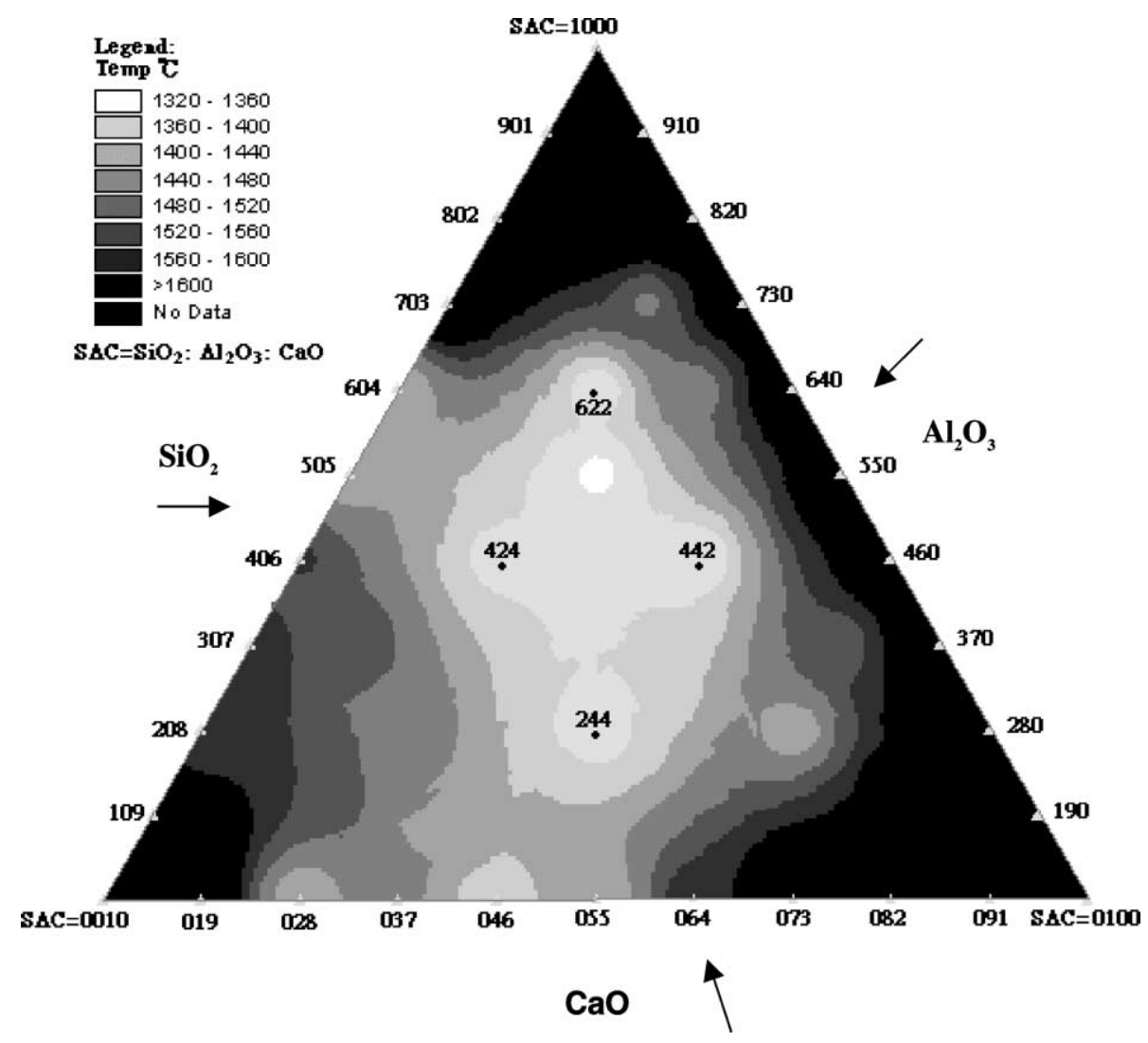

Fig. 3. Isotherms of pouring temperature under $\mathrm{CO}+\mathrm{CO}_{2}$ conditions for synthetic sludge ash. 
breviation for $\mathrm{SiO}_{2}, \mathrm{Al}_{2} \mathrm{O}_{3}$, and $\mathrm{CaO}$, and the associated numerical values indicate the weight ratio of $\mathrm{SiO}_{2}, \mathrm{Al}_{2} \mathrm{O}_{3}$ to $\mathrm{CaO}$ of the test samples. For example, $\mathrm{SAC}=631$ implies $\mathrm{SiO}_{2}: \mathrm{Al}_{2} \mathrm{O}_{3}: \mathrm{CaO}=6: 3: 1$. As shown in Fig. 2, an evidently low pouring temperature zone was bounded by a kite-shape formed by connecting points of SAC $=424$, 211, 442 and 244.

The low temperatures did not appear at previously reported value of $\mathrm{CaO} / \mathrm{SiO}_{2}=1$. This is partially due to the constituents present in the sludge $\left(\mathrm{Al}_{2} \mathrm{O}_{3}\right.$ in our system), which in turn influence its eutectic temperature (Murakami et al., 1991b; Chiang, 2001). Nonetheless, the basicity with a flexible operational area is preferred over a constant value in a narrow operational range due to unhomogenous nature in sludge.

The isotherms in Fig. 3 show that $\mathrm{CO} / \mathrm{CO}_{2}$ conditions significantly alter the pouring temperature for the synthetic sludge ash. The kite-shaped area ( $\mathrm{SAC}=622$, 424, 442 and 244) is larger than that in air melting

Table 2

Pouring temperature of sewage sludge molten slag

\begin{tabular}{lll}
\hline Melting conditions & Air & $\begin{array}{l}60 \% \mathrm{CO}+40 \% \\
\mathrm{CO}_{2}(\mathrm{w} / \mathrm{w})\end{array}$ \\
\hline $\begin{array}{l}\text { Sample size } \\
\text { Pouring temperature }\left({ }^{\circ} \mathrm{C}\right)\end{array}$ & 8 & 8 \\
$\quad$ Average temperature & 1220 & 1143 \\
$\quad$ Standard deviation & 0.5 & 6.5 \\
Melting temperature $\left({ }^{\circ} \mathrm{C}\right)$ & & \\
$\quad$ Average temperature & 1210 & 1130 \\
Standard deviation & 7.1 & 6.1 \\
\hline
\end{tabular}

Melting temperature: the temperature when the melted tested cone flows over the base and its height becomes half of the resulting bottom width. system (Fig. 2). The pouring temperature differences between $\mathrm{CO} / \mathrm{CO}_{2}$ and air conditions under varying SAC ratios ranged from $1{ }^{\circ} \mathrm{C}($ at SAC $=505)$ to $176^{\circ} \mathrm{C}$ (at $\mathrm{SAC}=622$ ), with an average of $24{ }^{\circ} \mathrm{C}$. The locations of relatively low pouring temperatures shown in Fig. 3 could also be indexed by $\mathrm{Al}_{2} \mathrm{O}_{3} / \mathrm{CaO}=0.5-2$ and $\mathrm{SiO}_{2}+\mathrm{CaO}=60-80 \%$.

The tendency of $\mathrm{CO} / \mathrm{CO}_{2}$ to exhibit lower pouring temperatures is also observed in the melting of sewage sludge ash (Table 2). The pouring temperature of 1143 ${ }^{\circ} \mathrm{C}$ under $\mathrm{CO} / \mathrm{CO}_{2}$ reducing conditions was much lower than that of $1220^{\circ} \mathrm{C}$ in air system, or a difference of 77 ${ }^{\circ} \mathrm{C}$. Table 2 also includes melting temperatures for comparison of the two systems; the same $80{ }^{\circ} \mathrm{C}$ difference.

\subsection{Effect of the reducing conditions on TCLP and XRD results}

The TCLP results (Table 3) show the compliance with Taiwan's regulatory standards for all samples including sludge ash. However, the melting conditions clearly affect metal leachability. As melting conditions switched from air to $\mathrm{CO} / \mathrm{CO}_{2}$, there exists one order of magnitude reduction for $\mathrm{Cu}$ (from 400 to $70 \mu \mathrm{g} / \mathrm{l}$ ) and $\mathrm{Zn}$ (from 7000 to $800 \mu \mathrm{g} / \mathrm{l}$ ). The exact reason(s) for the observed phenomenon is unknown; the presence of $\mathrm{CO} /$ $\mathrm{CO}_{2}$ must play an important role in tightly binding some metals.

The dominant and stable phase in XRD patterns for either air or $\mathrm{CO} / \mathrm{CO}_{2}$ case for the sewage sludge slag sample is $\mathrm{SiO}_{2}$, and to a lesser extent, $\mathrm{Fe}_{2} \mathrm{O}_{3}$ (Fig. 4). However, corundum $\left(\alpha-\mathrm{Al}_{2} \mathrm{O}_{3}\right)$ and some unidentified phases were identified under $\mathrm{CO} / \mathrm{CO}_{2}$ conditions. For practical purposes, the two XRD patterns are essentially the same.

Table 3

Heavy metal concentration in TCLP extracts of sewage sludge ash and sewage sludge molten slag

\begin{tabular}{|c|c|c|c|c|c|c|c|}
\hline \multirow[t]{2}{*}{ Heavy metals } & \multicolumn{2}{|c|}{ Sewage sludge $a^{a}{ }^{a}$} & \multicolumn{2}{|c|}{$\begin{array}{l}\text { Sewage sludge slag } \\
\text { (air condition) }^{\mathrm{b}}\end{array}$} & \multicolumn{2}{|c|}{$\begin{array}{l}\text { Sewage sludge slag } \\
\left(\mathrm{CO}+\mathrm{CO}_{2} \text { condition }\right)^{\mathrm{b}}\end{array}$} & \multirow{2}{*}{$\begin{array}{l}\text { Taiwan's regula- } \\
\text { tory thresholds } \\
(\mu \mathrm{g} / \mathrm{l})\end{array}$} \\
\hline & $(\mu \mathrm{g} / \mathrm{l})$ & $(\mathrm{mg} / \mathrm{kg})$ & $(\mu \mathrm{g} / \mathrm{l})$ & $(\mathrm{mg} / \mathrm{kg})$ & $(\mu \mathrm{g} / \mathrm{l})$ & $(\mathrm{mg} / \mathrm{kg})$ & \\
\hline As & ND & ND & 30 & 0.6 & 2 & 0.04 & 2500 \\
\hline $\mathrm{Cd}$ & 20 & 0.4 & 10 & 0.2 & 10 & 0.2 & 1000 \\
\hline $\mathrm{T}-\mathrm{Cr}$ & 100 & 2 & ND & ND & ND & ND & 2500 \\
\hline $\mathrm{T}-\mathrm{Hg}$ & ND & ND & ND & ND & ND & ND & 200 \\
\hline $\mathrm{Pb}$ & 100 & 2 & 60 & 1.2 & 10 & 0.2 & 5000 \\
\hline $\mathrm{Cu}$ & 3810 & 76 & 400 & 8 & 70 & 1 & 15000 \\
\hline $\mathrm{Zn}$ & 17660 & 353 & 7010 & 140 & 810 & 16 & 25000 \\
\hline $\mathrm{Ni}$ & NA & NA & 670 & 13 & 430 & 9 & $-^{\mathrm{c}}$ \\
\hline $\mathrm{Mn}$ & NA & NA & 400 & 8 & 50 & 1 & $-^{\mathrm{c}}$ \\
\hline
\end{tabular}

ND: not detected; NA: not analyzed.

${ }^{\text {a }}$ Analyzed by ICP-AES.

${ }^{\mathrm{b}}$ Analyzed by ICP-MS.

${ }^{\mathrm{c}}$ No regulatory limitation in Taiwan. 


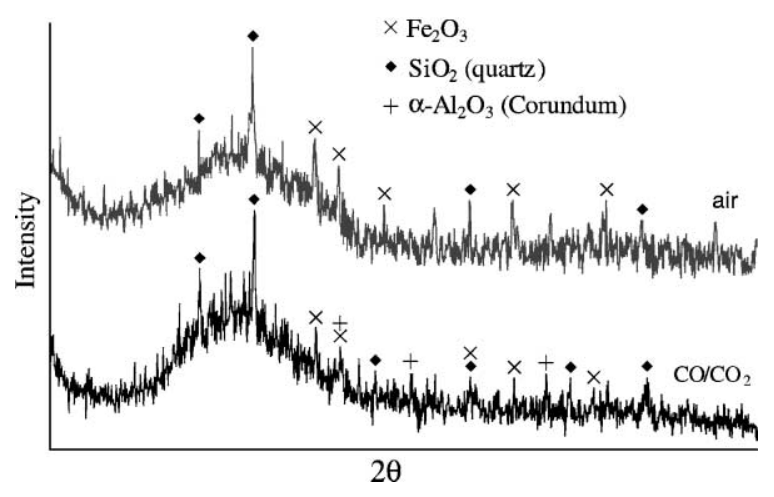

Fig. 4. X-ray diffractogram of sewage sludge slag from under air or $\mathrm{CO} / \mathrm{CO}_{2}$ conditions.

\section{Conclusions}

Reducing conditions generated by replacing air with $60 \% \mathrm{CO}+40 \% \mathrm{CO}_{2}$ effectively lowered the pouring temperature in the sludge melting process. The temperature differences of 24 and $77^{\circ} \mathrm{C}$ could be obtained for synthetic sludge ash composed of $\mathrm{SiO}_{2}, \mathrm{CaO}$ and $\mathrm{Al}_{2} \mathrm{O}_{3}$, and for sewage sludge ash, respectively. The leachability of heavy metals from the sludge slag is reduced for some metals as the melting conditions shifted from air to $\mathrm{CO} /$ $\mathrm{CO}_{2}$.

\section{Acknowledgements}

The authors would like to thank the National Science Council of the Republic of China for financial supporting this research under contract no. NSC 89-2211-E002-079.

\section{References}

Bijen, J., 1996. Benefits of slag and fly ash. Construction and Building Materials 10 (5), 309-314.

Chen, H.M., Ouyang, C.F., 1993. The characteristics of melting process on sewage sludge cake. Journal of Chinese Institute Environmental Engineering 3 (3), 169-177.

Chiang, H.-H., 2001. Basic study on materializes industrial sludge and water work sludge through co-melting process. Master Thesis, Nation Taiwan University, Taipei, Taiwan.
Endo, H., Nagayoshi, Y., Suzuki, K., 1997. Production of glass ceramics from sewage sludge. Water Science and Technology 36 (11), 235-241.

Kitamura, T., 1999. Coke-bed melting process for reuse sewage sludge. In: 7th IAWQ Asia-Pacific Regional Conference, Post-Conference Workshop on Sludge Management, pp. 113.

Murakami, T., Sasabe, K., Sasaki, K., Kawashima, T., 1991 a. Estimation of energy saving for melting process on sewage sludge. Water Science and Technology 23 (10/12), 20112018.

Murakami, T., Ishida, T., Sasabe, K., Sasaki, K., Harada, S., 1991b. Characteristics of melting process for sewage sludge. Water Science and Technology 23 (10/12), 2019-2028.

Nishino, J., Tahara, K., 1998. Melting properties of bottom and fly ashes derived from incineration of municipal waste. Journal of Ceramic Society of Japan 106 (11), 1117-1123 (in Japanese).

Ohshima, Y., Masuta, T., 1991. Sludge melting. Water Environment and Technology 23 (7), 68-71.

Oku, S., Kasai, T., Takeda, N., 1990. Melting system for sewage sludge. Water Science and Technology 22 (12), 319327.

Okuno, N., Takahashi, S., 1997. Full scale application of manufacturing bricks from sewage. Water Science and Technology 36 (11), 243-250.

Ozaki, M., Watanabe, H., Wiebusch, 1997. Characteristics of heavy metal release from incinerated ash, melted slag and their re-product. Water Science and Technology 36 (11), 267-274.

Republic of China-Environmental Protection Agency (ROCEPA), 1997. Methods of waste analysis. NIEA R201.11C.

Sakai, S., Hiraoka, M., Takeda, N., Tsunemi, T., 1990. Sewage sludge melting process: preliminary system design and fullscale plant study. Water Science and Technology 22 (12), 329-338.

Takaoka, M., Takeda, N., Miura, S., 1997. The behaviour of heavy metals and phosphorous in an ash melting process. Water Science and Technology 36 (11), 275-282.

Wang, K.S., Shao, B.C., 1993. Treatment of ashes from municipal solid waste and sewage sludge incinerator by melting process. In: Proceedings of 8th Conference on Waste Management Technology in Republic of China, pp. 351-370.

Wiebusch, B., Seyfried, C.F., 1997. Utilization of sewage sludge ashes in the brick and tile industry. Water Science and Technology 36 (11), 251-258.

Yashiki, D., Murakami, T., 1991. Operational results of melting system for sewage sludge. Water Science and Technology 23 (10/12), 1773-1781. 